\title{
Detection of Staphilococcus aureus by Amoxicillin Modified Natural Phosphate Electrode: Analytical Application Potato Juice
}

\section{Olivier François Aristide Bertrand Koffi ${ }^{1,2}$, Bernadette Ehui Avo Bile ${ }^{2}$, Edith Kwa-Koffi Kouassi ${ }^{2}$ and Abdelilah Chtaini $^{1^{*}}$}

${ }^{1}$ Electrochemestry and Molecular Inorganic Materials Laboratory, University Sultan Moulay Slimane, Faculty of Science and Technology, Morocco

2Laboratory of Physical Chemistry, University of Félix Houphouet-Boigny of Cocody, Côte d'Ivoire

"Corresponding author: Abdelilah Chtaini, Electrochemestry and Molecular Inorganic Materials Laboratory, University Sultan Moulay Slimane, Faculty of Science and Technology, Morocco, Tel: +212523485112; Fax: +212523485201; E-mail: a.chtaini@usms.ma

Red date: August 10, 2017; Acc date: August 30, 2017; Pub date: August 31, 2017

Copyright: $\odot 2017$ Koffi OFAB, et al. This is an open-access article distributed under the terms of the Creative Commons Attribution License, which permits unrestricted use, distribution, and reproduction in any medium, provided the original author and source are credited.

\begin{abstract}
The electrochemical detection of Staphylococcus aureus bacteria by the amoxicillin modified natural phosphate (AMX-Np) is decried. The AMX-NP electrodes were used for the detection of low optical densities of Staphylococcus aureus by using the cyclic voltammetry (cv) and the square waves voltammetry (swv). Some electrochemical properties, in particular the influence of the $\mathrm{pH}$, the optical density of the bacterium were studied. The elaborate electrode was the subject then of an analytical application for purposes of the detection of Staphylococcus aureus in the potato juice.
\end{abstract}

\section{Keywords: Modified electrodes; SWV; CV; Bacteria; Experimental}

Electrochemicalsensor

\section{Introduction}

The gilded staphylococcus (Staphylococcus aureus) is the stock of staphylococcus most frequently met in pathology human and veterinary. It shares with the bacterium Escherichia coli the unhappy privilege to be in the forefront of the germs responsible for infection nosocomial (infection contracted at the hospital) [1]. The Staphylococcus aureus is pathogenic opportunist which can cause various diseases at the human ones, energy of the affections which evolve spontaneously to the cure with pathologies mortals [2].The food poisoning by the staphylococcus is characterized by a brutal appearance of nauseas, vomiting, abdominal pains, cramps and of diarrhea $[2,3]$.

The food which facilitates the growth of the Staphylococcusis mainly pastry makings with the cream, dairy ice creams, the food treated such as hams, the pies and rillette, and tuna and poultry, the potato salads. Cooked products contaminated after cookings (chopped meats, fish, sectionsof pork-butchery). Products with water content reduced (saltings, fish dried and smoked, and dried milk) [4-6]. Cheeses, following an insufficient acidification of curd. Ovoproduits, mayonnaise, dairy products (e.g. condensed milk), creams, ices. The contaminated food has the same aspect (appearance, odor, taste) that the healthy food [7-9]. The placement of detector of this bacterium is essential in order to prevent the risks of contamination $[10,11]$. After the previously published work, which consisted in using the modified electrode AMX-NP for the detection and quantification of staphylococcus aurous [5], this work aims to use the same electrode in an analytical application, to face this analytical method under real conditions, In particular in potato juice.

\section{Reagent}

Before any handling, the solution was bubbled with ultrapure nitrogen for 5 minutes to degas the dissolved oxygen. The solutions were renewed for each experiment.

\section{Instrument}

The main component of the equipment used in this work consisted of a potentiostat of type Volta lab 10, assisted by the computer software Master 4. The measuring cell is made up of a system with three electrodes. A platinum plate with a surface area of $1 \mathrm{~cm} 2$, used as a reference electrode, the modified AMX-NP electrode is the seat of all reactions, thus called the working electrode and a saturated calomel electrode as reference electrode.

\section{Electrodes}

Firstly, the modified natural phosphate electrode was prepared according the following procedure [6]. The natural phosphate electrode was prepared by mixing the phosphate powder with amoxicillin and paraffin oil used as a binder.

The mixture was grinding in a mortar agate and then a portion of the resulting composite material was housed in PTFE cylinder. The geometric surface area of the working electrode was $0.1256 \mathrm{~cm} 2$. A bare of carbon vitreous inserted into carbon paste provided the electrical contact

\section{Analytical procedure}

Once the prepared electrode is ready, it is immersed in a solution containing a well-defined bacteria concentration, the effect of the contact time, called accumulation time, has been studied. After rinsing with distilled water, the electrode loaded with bacteria is transferred 
Citation: Koffi OFAB, Bile BEA, Kouassi Ekk, Chtaini A (2017) Detection of Staphilococcus aureus by Amoxicillin Modified Natural Phosphate

into the measuring cell containing the support electrolyte, $\mathrm{NaCl}$ (1 $\mathrm{mol} / \mathrm{L})$.

The cyclic and square wave voltammograms are recorded for different concentrations of bacteria, with a pulse of amplitude $5 \mathrm{mV}$ and the pitch of the potential is $50 \mathrm{mV}$ [12-14].

\section{Result and Discussion}

The electrode with natural phosphate paste modified by the amoxicillin with a concentration of $30 \mathrm{~g} / \mathrm{L}$ was characterized in the presence of bacteria with different density optical. In the presence of the bacteria, the electrode displays a significant increase in the density of current. This electrochemical behavior of the electrode is confirmed by the voltammetry square waves. The capacity of detection of the electrode thus increases with the increase in the bacterial load (Figure 1). This sensor was the subject of an electrochemical characterization by the cyclic voltammetry for identifying the duration of detection of the bacterium. Within sight of the results, it arises that after 50 cycles, corresponding to one hour duration six minutes $(1.06 \mathrm{~min})$, in the presence of the bacterium, the electrode displays an increase in the electro activity (Figure 2).

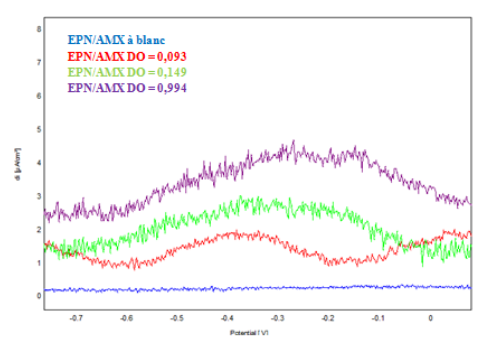

Figure 1: Superposition of the voltammogrammes with square waves of EPN/AMX ads. to white and EPN/AMX ads. (30 g/L) in the presence of the bacteria with various optical densities in $\mathrm{NaCl}$ to $0,1 \mathrm{M} ; \mathrm{v}=100 \mathrm{mV} / \mathrm{s}$, of $-2 \mathrm{~V}$ with $2 \mathrm{~V} ; \mathrm{pH}=7,42$.

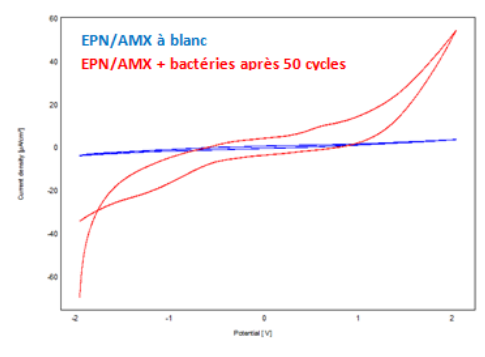

Figure 2: Comparison of the voltammogrammes cyclic of AMX-NP ads. with white and the bacteria after 50 cycles in $\mathrm{NaCl}$ to $0,1 \mathrm{M}$; $\mathrm{v}=100 \mathrm{mV} / \mathrm{s}$, of $-2 \mathrm{~V}$ with $2 \mathrm{~V}$; $\mathrm{pH}=7,42$.

A study of the influence of the $\mathrm{pH}$ on the electrochemical sensor in the presence of the bacteria was made. The electrode showed a good electro activity in the presence of the bacteria in the acid media, neutral and basic. We thus compared the aforementioned voltammogrammes in order to identify the medium which is most favorable for him. The results are illustrated by (Figure 3).

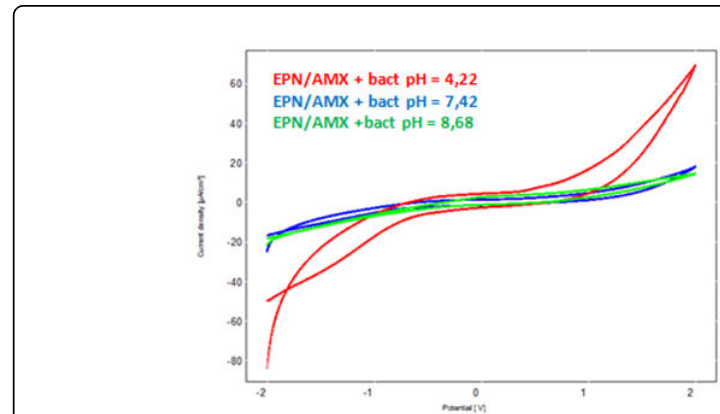

Figure 3: Superposition of the cyclic voltammogrammesof EPN/AMX ads. to different $\mathrm{pH}$ in the presence of the bacteria in $\mathrm{NaCl}$ to $0,1 \mathrm{M} ; \mathrm{v}=100 \mathrm{mV} / \mathrm{s}$, of $-2 \mathrm{~V}$ with $2 \mathrm{~V}$.

Taking into consideration these result, we can say that our electrode presents a better electro activity in acid medium, $\mathrm{pH}=4.22$.

\section{Analytical application in the potato juice}

Under the optimized conditions, the sensor (AMX-Np) was used for the detection of Staphylococcus aureus in sample of potato juices which were the subject of no preliminary treatment. The analytical application consisted in adding various quantities of physiological water containing the bacterium in the potato juice in order to vary the optical density and we have each time made an electrochemical characterization by using the voltammetry with square waves. These results are presented in Table 1 [15].

\begin{tabular}{|l|l|l|l|l|l|l|l|l|}
\hline DO & 0 & 0,410 & 0,520 & 0,661 & 0,733 & 0,818 & 0,912 & 0,991 \\
\hline $\mathbf{d i}\left(\boldsymbol{\mu A} / \mathbf{c m}^{2}\right)$ & $\begin{array}{l}1,4 \\
5\end{array}$ & 1,679 & 1.995 & 1,980 & 2,105 & 2,063 & 2,155 & 2,351 \\
\hline
\end{tabular}

Table 1: Density of current according to the optical density

Figure 4 shows the variation of the density of current according to the optical density.

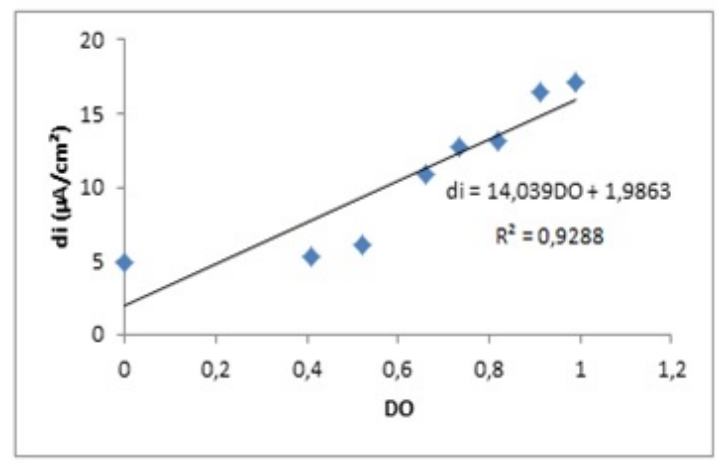

Figure 4: Density of current according to the optical density

The density of current increases with the evolution of the optical density of the bacteria, measured using a spectrophotometer. Figure 4 shows a typical linear answer, which can be expressed according to the following equation: $\mathrm{di}=14,039 \mathrm{DO}+1,9863$. 
Citation: Koffi OFAB, Bile BEA, Kouassi Ekk, Chtaini A (2017) Detection of Staphilococcus aureus by Amoxicillin Modified Natural Phosphate Electrode: Analytical Application Potato Juice. Gen Med (Los Angeles) 5: 295. doi:10.4172/2327-5146.1000295

Page 3 of 3

\section{Comparison of the characteristics of the electrochemical sensor (SD, LD et LQ)}

Taking into consideration these result, it arises that the electrochemical sensor being studied, shows a better SD, LD and LQ in the potato juice in Table 2. This result comes to confirm the effectiveness of this sensor, considering the potato juice is a hostile environment with the bacteria. Indeed the potato juice contains certain active molecules anti-bacterial in the fight against the bacteria (the Helicobacter pylori) responsible for the ulcer of the stomach [16].

\begin{tabular}{|l|l|l|l|}
\hline \multirow{2}{*}{ Sensor } & \multirow{2}{*}{\begin{tabular}{l} 
Characteristic \\
\cline { 3 - 4 }
\end{tabular}} & & Analytical mediums \\
\cline { 3 - 4 } & & Electrolyte support & $\begin{array}{l}\text { Potato } \\
\text { juice }\end{array}$ \\
\hline AMX-NP(adsorption) & $\mathrm{SD}\left(\mu \mathrm{A} / \mathrm{cm}^{2}\right)$ & $5,800.10-7$ & $6,350.10-9$ \\
\hline & LD & $4,900.10-7$ & $2,218.10-8$ \\
\hline & LQ & $1,635.10-6$ & $7,390.10-8$ \\
\hline
\end{tabular}

Table 2: Sensibilities of detection (SD), Limitate detection (LD) and limits of quantification (LQ) of the bacterium according to analytical mediums'.

\section{Conclusion}

The electrochemical sensor (AMX-Np) is extremely sensitive to the bacterium. The $\mathrm{pH}$ has an influence on the electro activity of this electrode and the acid medium seems more favorable. Also, its duration of detection is satisfactory. The analytical study in a potato juice sample showed good results.

\section{References}

1. Murray PR, Baron EJ, Jorgensen JH, Landry ML, Faller MAP, et al., (2003) Manual of Clinical Microbiology (8th ed.), Herdon, VA, United States of America: American Society for Microbiology.

2. Loir Y, Baron F, Gautier M (2003) Staphylococcus aureus and food poisoning. Genet Mol Res 2: 63-76.
3. http://www.liste-hygiene.org/STAPHY.htmlsite.

4. Adams M, Moss M (2008) Food microbiology (3rdedtn), UK RSC press, 252- 256.

5. Center for Disease Control and Prevention (2011) Estimates of Food borne Illness in the United States.

6. Bean NH, Griffins PM (1990) Foodborne Disease Outbreaks in the United States, 1973-1987 Pathogens, Vehicles, and Trends. J Food Microbiol 53: 804-817.

7. Bryan FL, Michanie SC, Alvarez P, Paniagua A (1988) Critical control points of street-vended foods in the Dominican Republic. J Food Prot 51: 373-383.

8. Tambekar DH, Jaiswal VJ, Dhanorkar DV, Gulhane PB, Dudhane MN (2008) Identification of microbiological hazards and safety of ready-toeat food vendee in streets of Amravati City, India. J Appl Biosci 7: 195-201.

9. Mankee A, Ali S, Chin A, Indalsingh R, Khan R, et al. (2003) Bacteriological Quality of doubles sold by street vendors in Trinidad and the attitudes, knowledge and perceptions of the public about its consumption and health risk. Food Microbiol 20: 631-639.

10. Berlutti F, Rosso F, Bosso P, Giansanti F, Ajello M, et al. (2003) Quantitative evaluation of bacteria adherent to polyelectrolyte HEMAbased hydrogels. J Biomed Mater Res A 67: 18e25.

11. Prodromidis MI (2010) Impedimetricimmunosensors- A review. Electrochim Acta 55: 4227-4223.

12. Bertrand OFAK, Bea B, Belkhouya N, Chtaini A (2016) A Natural Phosphate Electrode Modified with Antibiotic for the Detection of Bacteria. J BiosensBioelectron 7: 202.

13. come4news.com/pomme-de-terre-et-ulcere-destomac, site visité le $6 / 12 / 2016$

14. Gomdje VH, Ngono TRL, El quoatli SE, Najih R, Chtaini A (2013) Acta Technica Corviniensis 6 : 139-142.

15. Engelsman AF, van der Mei HC, Francis KP, Busscher HJ, Ploeg RJ, et al. (2009) Real time noninvasive monitoring of contaminating bacteria in a soft tissue implant infection model. J Biomed Mater Res B Appl Biomater 88: $123 \mathrm{e} 9$.

16. Grysakowski B, Jasielec J, Wierzba B, Sokalski T, Lewenstam A, et al. (2011) Electrochemical Impedance Spectroscopy (EIS) of ion sensors: Direct modeling and inverse problem solving using the Nernst-PlanckPoisson (NPP) model and the HGS(FP) optimization strategy. J Electroanal Chem 662: 143-149. 